adjusting the dosage of thyroid hormones, and the formulation of different ratios of the two hormones to achieve "normal" serum P.B.I. values is pointless if thyroxine alone relieves all the features of hypothyroidism. Thyroxine was well tolerated by patients in this trial, which accords with previous clinical experience, and it can be given conveniently as a single daily dose because it has a long biological half-life. There is no published evidence that patients treated with thyroxine alone suffer any ill effects due to the absence of triiodothyronine.

Fixed-ratio combinations of triiodothyronine and thyroxine cannot be expected to mimic precisely the continuous endogenous secretion of thyroid hormones because the rapid absorption and high biological activity of the triiodothyronine component may produce fluctuations in metabolic activity with untoward symptoms. Other studies have devoted most attention to the effects of combined preparations on laboratory tests, which have limited therapeutic importance in this situation (Harland and Orr, 1969), and have failed to conduct a valid clinical comparison. The shortcomings of combined therapy deduced from this study suggest that thyroxine has overall advantages for thyroid replacement therapy.

Glaxo Laboratories Ltd. supplied the combined tri-iodothyronine and thyroxin, the thyroxine (Eltroxin), and also the Triosorb 131 kits (Abbott Laboratories Ltd.). Mr. J. D. Cronin, chief pharmacist, and his staff at the Royal Infirmary, issued the coded tablets. We thank Dr. A. Jordan, Professor R. Kilpatrick, Professor D. S. Munro, and Dr. A. J. Smith in the two departments for their criticism of the manuscript and, finally, Professor G. M. Wilson for his advice in the planning of the trial.
REFERENCES

Alley, R. A., et al. (1968). Metabolism, 17, 97.

Catz, B., Ginsburg, E., and Salenger, S. (1962). New England fournal of

Medicine, 266, 136 .
Devlin, W. F., and Stephenson, N. R. (1962). Journal of Pharmacy and Pharmacology, 14, 597.

Devlin, W. F., and Watanabe, H. (1966). Journal of Pharmaceutical Sciences, $55,390$.

Frawley, T. F., McClintock, J. C., Beebe, R. T., and Marthy, G. L. (1956). Fournal of the American Medical Association, 160, 646.

Gatley, M. S. (1968). Journal of the Royal College of General Practitioners, $16,39$.

Goolden, A. W. G. (1969). Personal communication.

Goolden, A. W. G., Gartside, J. M., and Sanderson, C. (1967). Lancet, 1, 12.

Harland, W. A., and Orr, J. S. (1969). Scottish Medical fournal, 14, 375.

Hedley, A. J., Flemming, C. J., Chesters, M. I., Michie, W., and Crooks, J. (1970). British Medical fournal, 1, 519.

Kologlu, S., Schwartz, H. L., and Carter, A. C. (1966). Endocrinology, 78,

231.
Lavietes, P. H., and Epstein, F. H. (1964). Annals of Internal Medicine, $60,79$.

Lemieux, R., and Talmage, J. M. (1966). Journal of Pharmacy and Pharmacology, 18, 94.

Levy, R. P., Marshall, J. S., and McGuire, W. L. (1964). Metabolism, 13,

Macgregor, A. G. (1961). Lancet, 1, 329

Mitchell, M. L., Harden, A. B., and O'Rourke, M. E. (1960). Fournal of Clinical Endocrinology and Metabolism, 20, 1474.

Pileggi, V. J., Golub, O. J., and Lee, N. D. (1965). Fournal of Clinical Endocrinology and Metabolism, 25, 949.

Porter, A. M. W. (1969). British Medical fournal, 1, 218.

Sachs, B. A., Wolfman, L., and Murthy, G. (1968). Amcrican Journal of the Medical Sciences, 256, 232.

Selenkow, H. A., and Wool, M. S. (1967). Annals of Internal Medicine, 67, 90.

Taylor, S. (1961). Lancet, 1, 341.

Taylor, S., Kapur, M., and Adie, R. (1970). British Medical fournal, 2, 270.

Wiberg, G. S., Devlin, W. F., Stephenson, N. R., Carter, J. R., and Blayne, A. J. (1962). Journal of Pharmacy and Pharmacology, 14, 777.

Wool, M. S., and Selenkow, H. A. (1965). Clinical Pharmacology and Therapeutics, 6, 710.

\title{
Comparison of the Efficacy of Liquid and Freeze-dried Strains of B.C.G. Vaccine in Preventing Tuberculosis
}

\author{
V. H. SPRINGETT, ${ }^{*}$ M.D., F.R.C.P. ; IAN SUTHERLAND, $\dagger$ M.A.; D.PHIL.
}

\begin{abstract}
Cummary: Analysis of the tuberculosis notifications and the statistics of B.C.G. vaccinations among 13-year-old schoolchildren in Birmingham, England, between 1953 and 1969 shows that the Copenhagen strain of B.C.G. (liquid batches issued 1953-61) and the Glaxo Laboratories strain (freeze-dried batches issued 1962-68) were of similar high efficacy in the prevention of tuberculosis. The method of analysis could be used for the surveillance of the protective efficacy of B.C.G. vaccine in other population groups where it is used routinely but not universally.
\end{abstract}

\section{Introduction}

In an earlier paper one of us reported the results of B.C.G. vaccination of 13-year-old Birmingham schoolchildren during 1956-67 (Springett, 1969). The analysis of results was directed towards the age distribution of the tuberculosis notifications and to detecting any secular trend in the notifications in vaccinated and other groups. It is also possible to analyse the results in terms of periods of vaccination. The object of this paper is to report such a comparison for the periods before and after 16 December, 1961, when the change was made in

\footnotetext{
- Medical Director, Birmingham Chest Service. t Director, M.R.C. Statistical Research and Services Unit, London
W.C.1.
}

Birmingham from liquid B.C.G. vaccine (Copenhagen strain) to freeze-dried B.C.G. vaccine (Glaxo laboratories strain).

\section{Method}

For the purpose of this comparison the following additional data have been extracted from the records: (a) information for a further two years of follow-up (1968 and 1969) and for a further two cohorts of children (aged 13 years last birthday on 31 August in 1967 and in 1968); and (b) a separation of the published follow-up information for the two-year period 1962-3 into the calendar years 1962 and 1963-this permits the follow-up of the earlier cohorts (given liquid vaccine) to be terminated, for the purpose of this study, after about the same duration and over the same range of ages as is now available for the later cohorts (given freeze-dried vaccine).

The basic information has been assembled and the calculations have been performed, in exactly the same way as was done by Springett (1969). In particular the numbers of unvaccinated tuberculin-negative subjects, and the notifications of tuberculosis among them, were estimated from the figures for all non-participants in the vaccination scheme, $(a)$ by reducing the total number of non-participants by the proportion of particinants who were tuberculin-positive, and $(b)$ by reducing the total cases of tuberculosis among non-participants by the numbers expected (from the known experience of the 
Incidence of Notified Tuberculosis in Subjects Given Liquid Danish or Freeze-dried British B.C.G. Vaccine, and in Tuberculin-negative Unvaccinated Subjects Observed Concurrently. Birmingham, England, 1953 to 1969.

\begin{tabular}{|c|c|c|c|c|c|c|c|c|c|c|c|c|c|}
\hline \multirow[b]{2}{*}{$\begin{array}{l}\text { B.C.G. Vaccine } \\
\text { and Strain }\end{array}$} & \multirow{2}{*}{$\begin{array}{c}\text { Age 13 } \\
\text { Years Last } \\
\text { Birthdayy } \\
\text { on 31 } \\
\text { August } \\
\text { in Years }\end{array}$} & \multirow{2}{*}{$\begin{array}{l}\text { Calendar } \\
\text { Period of } \\
\text { Observa- } \\
\text { tion of } \\
\text { Cohorts }\end{array}$} & \multicolumn{5}{|c|}{ Vaccinated Subjects } & \multicolumn{5}{|c|}{ Unvaccinated (Tuberculin-negative) Subjects } & \multirow{2}{*}{$\begin{array}{c}\text { Ratio of } \\
\text { Rates in } \\
\text { Vaccinated } \\
\text { nd Un- } \\
\text { vaccinated } \\
\text { Subjects } \\
(\%)\end{array}$} \\
\hline & & & Total & $\begin{array}{c}\text { Person- } \\
\text { years of } \\
\text { Obuerva- } \\
\text { tion }\end{array}$ & $\begin{array}{c}\text { Average } \\
\text { Observa- } \\
\text { tion } \\
\text { (Years) }\end{array}$ & $\begin{array}{c}\text { Notifica- } \\
\text { tions of } \\
\text { Tubercu- } \\
\text { losis }\end{array}$ & $\begin{array}{c}\text { Annual } \\
\text { Rate } / \\
10,000\end{array}$ & $\begin{array}{c}\text { Esti- } \\
\text { mated } \\
\text { Totalt }\end{array}$ & $\begin{array}{l}\text { Person- } \\
\text { years of } \\
\text { Observa- } \\
\text { tion }\end{array}$ & $\begin{array}{c}\text { Average } \\
\text { Observa- } \\
\text { tion } \\
\text { (Years) }\end{array}$ & $\begin{array}{c}\text { Estimated } \\
\text { Notifica- } \\
\text { tions of } \\
\text { Tubercu- } \\
\text { losist }\end{array}$ & $\begin{array}{c}\text { Annual } \\
\text { Rate } / \\
10,000\end{array}$ & \\
\hline $\begin{array}{l}\text { Jiquid (Copenhagen).. } \\
\text { Freeze-dried (Glaxo) .. }\end{array}$ & $\begin{array}{l}1953-61^{*} \\
1961-8^{*}\end{array}$ & $\begin{array}{l}1956-62 \\
1962-9\end{array}$ & $\begin{array}{l}85,327 \\
88,562\end{array}$ & $\begin{array}{l}371,414 \\
395,315\end{array}$ & $\begin{array}{l}4 \cdot 35 \\
4 \cdot 46\end{array}$ & $\begin{array}{l}21 \\
17\end{array}$ & $\begin{array}{l}0.57 \\
0.43\end{array}$ & $\begin{array}{l}37,331 \\
21,748\end{array}$ & $\begin{array}{r}188,056 \\
97,429\end{array}$ & $\begin{array}{l}5 \cdot 04 \\
4 \cdot 48\end{array}$ & $\begin{array}{l}94 \cdot 6 \\
62 \cdot 4\end{array}$ & $\begin{array}{l}5 \cdot 03 \\
6 \cdot 40\end{array}$ & $\begin{array}{r}11.3 \\
6.7\end{array}$ \\
\hline
\end{tabular}

-Vaccinations up to 16 December 1961 were with liquid Danish vaccine, thereafter with freeze-dried British vaccine.

The method of derivation of these figures is outlined in the text and fully explained by Springett (1969).

tuberculin-positive participants) in a group of tuberculinpositive non-participants of the estimated size. The results are given in the Table.

\section{Results}

The incidence of notified tuberculosis in the vaccinated subjects is much lower than the estimated incidence among the tuberculin-negative unvaccinated subjects observed concurrently. For subjects given liquid vaccine the incidence of notified tuberculosis is $11.3 \%$ of that estimated for unvaccinated tuberculin-negative subjects; for those given freezedried vaccine the incidence is $6.7 \%$. Because the groups were not established by random allocation these figures cannot provide precise estimates of the efficacy of the vaccines. Nevertheless, the substantial contrasts in incidence between the vaccinated and the tuberculin-negative unvaccinated subjects indicate that both strains of B.C.G. vaccine must have been highly effective.

The maintenance of a high tuberculosis incidence in unvaccinated subjects is associated with the arrival in Birmingham, during the freeze-dried period, of many immigrants from Asia, who are represented as vaccinated and tuberculin-positive subjects and as non-participants in the scheme. Because the numbers of immigrants in these categc ries each year are not known, an exact subdivision of the to al figures for the freeze-dried period into those for the immigrant and nonimmigrant populations is not possible. Nevertheless, the effects of a wide range of plausible assumptions about the numbers of immigrants, the extent of their participation in the scheme, and the level of tuberculin positivity among them have been examined.

The results are not reported in full here, but they show that the effect of combining the figures for a small high-incidence group of immigrants (British Tuberculosis Association, 1966), probably participating less fully in the scheme, with those for the native-born population is in general to reduce the observed ratio of the rates in the vaccinated and unvaccinated groups below the value it would have had for the native-born population alone. Over the range of assumptions studied the value of the ratio for the native-born population alone ranged from 7.7 to $9.4 \%$. (The corresponding ratios for the immigrant population alone were very much more dependent on the particular set of assumptions and give no indication whether the efficacy of the freeze-dried vaccine in the immigrant population was the same as, or different from, that in the native-born population.) For the native-born population the similarity of the ratio in those given the liquid vaccine $(\mathbf{1 1 . 3} \%)$ and in those receiving the freeze-dried vaccine (about $9 \%$ ) indicates that these two strains must have been of similar high efficacy.

\section{Discussion}

The efficacy of a large number of batches of liquid B.C.G. vaccine (Copenhagen strain) issued in 1950-2 was determined in a controlled trial in Britain (Medical Research Council, 1956, 1959, 1963). Over a five-year period (about the same as that studied here) the efficacy of the vaccine against tuberculosis was $83 \%$ (Medical Research Council, 1959). Alternatively expressed, the ratio of the rates in the vaccinated and unvaccinated subjects was $17 \%$.

The present study is not a controlled trial. The estimates of the experience of the unvaccinated subjects were, however, derived from the assumption that the tuberculosis experience and exposure of the non-participants in the scheme was typical of that of the participants; this is analogous to the situation in a controlled trial, where the random allocation of subjects ensures the similarity of the tuberculosis exposure of the unvaccinated and vaccinated groups. In this study the ratio of the rates in the vaccinated and unvaccinated groups for the liquid vaccine was $11.3 \%$, which is lower than that found in the controlled trial. One interpretation of this finding is that the batches of liquid B.C.G. vaccine (Copenhagen) issued in 1953-61 were slightly more effective than those issued in 1950-2; this may be so, because there were improvements during the earlier period in the metho is of manufacture and issue of the vaccine (Tolderlund, 1952; Hart et al., 1967). An alternative explanation is that the tuberculosis experience and exposure of the non-participants in the present study may have been rather greater than those of the participants. In all, the evidence indicates that the later batches of liquid B.C.G. vaccine (Copenhagen strain) were no less effective in routine use in Britain than the earlier batches used in the controlled trial.

The corresponding ratio for the freeze-dried vaccine in the native-born population was about $9 \%$, and similar considerations apply to the interpretation of this figure. In all, the evidence indicates that the batches of freeze-dried B.C.G. vaccine (Glaxo Laboratories strain) in routine use in Britain in 1962-8 (which all contained between 4 and 9 million viable units per $\mathrm{ml}$. reconstituted vaccine) were no less effective than the batches of liquid B.C.G. vaccine (Copenhagen strain) used in 1953-61.

This analysis provides the first direct evidence of the high efficacy of this freeze-dried B.C.G. vaccine against tuberculosis in Britain. The same vaccine has already been shown in controlled trials to have a high efficacy against leprosy in Uganda (Kinnear Brown et al., 1966, 1968) and, for reasons not yet understood, a much lower efficacy against leprosy in Burma (Bechelli et al., 1970).

In many countries it is no longer practicable to mount a controlled trial of the efficacy of different B.C.G. vaccines. The present investigation indicates an alternative approach, in a country in which B.C.G. is not universal, consisting essentially of the surveillance of the effects of B.C.G. vaccine in routine use. This could be used either to compare the efficacy of two vaccines in simultaneous use in a country or, as in the present instance, to assess whether the efficacy of the vaccines is being maintained óver a period of time. The method cannot provide an absolute measure of efficacy (for which a controlled trial would be needed) but does offer an approximate criterion. For example, a vaccine could be regarded as having a satisfactorily high efficacy if the ratio of the notification rates in vaccinated and unvaccinated tuberculin-negative subjects was less than $25 \%$. 
Bechelli, L. M., et al. (1970). Bulletin of the World Health Organization, 42,235 .

British Tuberculosis Association (1966). Tubercle, 47, 145.

Brown, J. A. K., Stone, M. M., and Sutherland, I. (1966). British Medical fournal, 1,7.

Brown, J. A. K., Stone, M. M., and Sutherland, I. (1968). British Medical fournal, 1, 24.
Hart, P. D'A., Sutherland, I., and Thomas, J. (1967). Tubercle, 48, 201

Medical Research Council (1956). British Medical fournal, 1, 413.

Medical Research Council (1959). British Medical fournal, 2, 379.

Medical Research Council (1963). British Medical fournal, 1, 973.

Springett, V. H. (1969). Tubercle, 50, 159.

Tolderlund, K. (1952). Acta Pathologica et Microbiologica Scandinaeica, Suppl., 93, 299.

\title{
Effect of Temperature on Hospital Admissions for Myocardial Infarction in a Subarctic Area
}

\author{
E. SOTANIEMI,* M.D. ; U. VUOPALA, $†$ M.D. ; E. HUHTI, † M.D. ; J. TAKKUNEN, $\ddagger$ M.D.
}

British Medical Fournal, 1970, 4, 150-151

\begin{abstract}
Ummary: In a study of the effect of mean daily tempera$\checkmark$ ture on the admission and fatality rates of 771 patients with myocardial infarction the admission rate was found to be significantly higher on cold (temperature below $0^{\circ} \mathrm{C}$.) than on warm (temperature above $0^{\circ} \mathrm{C}$.) days. The fatality rate was almost equal in cold and warm weather. Thus the seasonal fluctuation in the admission rate of patients with myocardial infarction is probably due to a direct effect of environmental temperature.
\end{abstract}

\section{Introduction}

A seasonal fluctuation has been noted in numerous studies concerning the incidence of myocardial infarction. In the temperate and cold zones it has generally been found to be higher in winter than in summer (Bean and Mills, 1938; Ekvall, 1955; Dotzauer and Naeve, 1956; Gorbatow, 1961; Vartio et al., 1964; Rose, 1966), but there are exceptions (Mintz and Katz, 1947; Master and Jaffe, 1952; Westlund, 1965). On the other hand, in subtropical regions there is a definite increase in the hospital admission rate of myocardial infarction during the hot summer months compared with the cooler winter months (Heyer et al., 1953; DePasquale and Burch, 1961). Thus the relation between environmental temperature and myocardial infarction is still uncertain.

Other problems that remain unsolved are whether the fatality rate of myocardial infarction increases with a deviation from the optimum temperature (Lancet, 1970), and whether temperature variations may have different effects in different countries, as some of the results seem to suggest (Anderson and Le Riche, 1970). The incidence of respiratory infections increased during the cold season (Holland et al., 1961), and Anderson and Le Riche (1970) thought that the seasonal fluctuation in the mortality from ischaemic heart disease was mainly due to the seasonal fluctuation in respiratory disease. If this is the case one would expect the fatality rate to be higher among patients with myocardial infarction entering hospital during the cooler periods of the year, when the respiratory infections are more prevalent.

We present the results of an investigation into the relation between myocardial infarction and the environmental temperature. The patients came from a limited area in the North of Finland, where a subarctic climate prevails and the differences between seasonal temperatures are pronounced.

\footnotetext{
* Senior Lecturer in Medicine.

Physician.

Associate Professor in Medicine.

Department of Medicine, University of Oulu, Oulu, Finland.
}

\section{Patients and Methods}

$\mathrm{Al}$ ! patients with myocardial infarction treated at the deparment of medicine, University of Oulu, from 1965 to 1968 are included-a total of 771 cases. The population of the area served by the hospital is about 300,000 , but some patients are admitted into the smaller hospitals, and, because of the long distances, do not reach the hospital until after the onset of intarction. Most of the patients come from the city of Oulu (population 90,000) and the surrounding rural districts. Diagnisis was based on the usual anamnestic, clinical, laboratory, and electrocardiographic criteria.

Oulu is situated on the Gulf of Bothnia in Northern Finland, almos: exactly at latitude $65^{\circ} \mathrm{N}$. Its mean annual temperature during the period of investigation was $+1.2^{\circ} \mathrm{C}$. (the mean temperature for the coldest month being $-15.9^{\circ} \mathrm{C}$. and $\mathrm{Co}^{\circ}$ the warmest month $+15.4^{\circ} \mathrm{C}$.) and the mean annual rair all $512 \mathrm{~mm}$.

The investigatun covered 1,461 days. The daily mean temperatures were recurded by the meteorological station at Oulu airport. The days were divided into seven groups according to their mean temperatures: the coldest group included the days with a mean temperature below $-30^{\circ} \mathrm{C}$. and the warmest those with a mean temperature above $+20^{\circ} \mathrm{C}$. The other groups lay between these extremes. The number of patients with myocardial infarction admitted to hospital each day was then ascertained, and distributed into the above-mentioned day groups. The fatality rate in each group during the hospital stay was also calculated; the length of stay-three or four weeks, according to the severity of infarction (Takkunen et al., 1969)-was equal in all groups. As no difference was found in the distribution of patients with first and subsequent infarctions, these two groups were combined.

\section{Results}

The distribution of patients into groups based on the daily mean temperatures is shown in the Table. On 867 days (59\%)

Effect of Mean Daily Temperature on Admissions for and Prognosis of Myocardial Infarction

\begin{tabular}{|c|c|c|c|c|c|c|c|c|c|}
\hline \multirow{2}{*}{$\begin{array}{c}\text { Daily } \\
\text { Temperature } \\
\left({ }^{\circ} \mathrm{C} .\right)\end{array}$} & \multicolumn{2}{|c|}{ Days } & \multicolumn{3}{|c|}{$\begin{array}{l}\text { Myocardial } \\
\text { Infarctions }\end{array}$} & \multicolumn{3}{|c|}{ Deaths } & \multirow{2}{*}{$\begin{array}{c}\text { Fatality } \\
\text { Rate } \\
(\%)\end{array}$} \\
\hline & No. & "10 & No. & "o & $\begin{array}{l}\text { Per } \\
\text { Day }\end{array}$ & No. & \% & $\begin{array}{l}\text { Per } \\
\text { Day }\end{array}$ & \\
\hline $\begin{array}{r}r-30 \\
30-20 \\
-19-10 \\
+9-+0 \\
+0+9 \\
+10-+19 \\
+20-+30\end{array}$ & $\begin{array}{r}7 \\
79 \\
163 \\
345 \\
458 \\
394 \\
15\end{array}$ & $\begin{array}{r}0.5 \\
5.4 \\
11.0 \\
23.7 \\
31.4 \\
27.0 \\
1.0\end{array}$ & $\begin{array}{r}5 \\
53 \\
125 \\
202 \\
200 \\
178 \\
8\end{array}$ & $\begin{array}{r}0.6 \\
6.9 \\
16 \cdot 3 \\
26 \cdot 1 \\
26 \cdot 0 \\
23.1 \\
1.0\end{array}$ & $\begin{array}{l}0.71 \\
0.67 \\
0.76 \\
0.59 \\
0.44 \\
0.45 \\
0.55\end{array}$ & $\begin{array}{r}0 \\
15 \\
37 \\
58 \\
49 \\
45 \\
1\end{array}$ & $\begin{array}{c}0 \\
7.3 \\
18.0 \\
28.3 \\
24.0 \\
21.9 \\
0.5\end{array}$ & $\begin{array}{l}0 \\
0 \cdot 19 \\
0 \cdot 23 \\
0 \cdot 17 \\
0 \cdot 10 \\
0 \cdot 11 \\
0.07\end{array}$ & $\begin{array}{c}0 \\
28 \cdot 3 \\
29 \cdot 6 \\
28 \cdot 7 \\
24 \cdot 5 \\
25 \cdot 3 \\
12 \cdot 5\end{array}$ \\
\hline
\end{tabular}

